\title{
Effects of Visualization on Academic Performance of College Students
}

\author{
Niño Fredrico L. Narvacan, Evangeline Atienza-Bulaquiña, and Lucille D. Evangelista
}

\begin{abstract}
This study investigated the effects of visualization on college students' academic performance. One control group and two experimental groups were utilized. The participants were the first year Bachelor of Science in Psychology students of Batangas State University. Results obtained from the experiment showed that visualization has no significant effect on the academic performance of the two experimental groups. However, grade improvements were higher in these treatments compared to the control group. The students' performance before and after the visualization showed a computed $p$-value of 0.16 and 0.20 respectively, higher than 0.05 level of significance which failed to reject the null hypothesis. On the other hand, the control group showed significant effect which yielded a p-value of 0.009 lower than the 0.05 level of significance. The results also showed a chi-square value of 0.163 for experimental groups 1 and 2 which made the two approaches equally significant in improving academic performance.
\end{abstract}

Index Terms-Academic performance, college student, positive psychology, visualization.

\section{INTRODUCTION}

Visualization is a process of cognitive stimulation to direct things imagined to work. According to Jack Canfield (2005) in order to reach a goal, one has to visualize the goal "as already complete in vivid detail, and then allow yourself to feel that result of your goal (fuel the emotions)" [1].

Tal Ben-Shahar, an author and lecturer of Positive Psychology at Harvard University, mentioned during one of his lectures that a study by Shelley Taylor, Ph.D., a psychologist at University of California, Los Angeles (UCLA), conducted an experiment on how visualization affects individuals in achieving goals. This study became the basis and framework of the researchers' experimentation.

Science has indeed shown that visualization does work to some extent, primarily in the field of Sports Psychology. An experiment done by Australian psychologist Alan Richardson has revealed that athletes who visualized shooting free throws did just as well as those who actually practiced [2]. A study in Ohio by GuangYue, an exercise psychologist from Cleveland Clinic foundation, showed that by visualizing weightlifting, athletes gained muscle mass nearly as much as half the mass as those who actually trained; and prominent athletes who use visualization in sports are Tiger Woods, Jack Nicklaus, and Muhammad Ali [3].

Manuscript received June 25, 2013; revised November 8, 2013.

N. L. Narvacan and E. A. Bulaquiña are with Batangas State University, Batangas City, 4200, Philippines (e-mail: nicolandichonarvacan@gmail.com evangeline1119@yahoo.com).

L. D. Evangelista is with the College of Arts and Sciences, Batangas State University, Batangas City, 4200, Philippines (e-mail: balotevangelista@yahoo.com).
Thoughts generate the similar mental "instructions as actions" according to brain studies. Cognitive processes are affected by mental simulation. Doing mental exercises can improve one's effectiveness in performance and motivation. It can also increase confidence and chance for success in any endeavours in life [3].

Mental exercise can be practiced as one of the ways to attainsuccess [3]. This notion of cognitive exercise aroused the researchers' interest to conduct the study to help students become more optimistic in their studies. Moreover, they wanted to determine how visualization can help improve students' performance by acquiring better study habits and positive behavior towards schooling.

In this generation of modern advancement, changes greatly affect students' mindset toward schooling. Some of them become very negative or unconcerned with their studies even during examinations and tend to get low grades. Lack of motivation and positive thinking is one of the factors that affect poor performance. This investigation aimed to know the effect of visualization in students' academic performance. To determine a more effective method of visualization was also the thrust of the study.

\section{METHOdOLOGY}

\section{A. Research Design}

This study is a true experimental design. It specifically investigated the effects of visualization among first year BS Psychology students' academic performance to determine if this method can improve performance, study habits, and positivity. The statistical treatments used were mean, standard deviation, paired t-test, independent $\mathrm{t}$-test, and chi-square.

\section{B. Participants}

The participants in this study were the first year BS Psychology students of Batangas State University. The samples were chosen using multistage sampling technique particularly stratified proportional sampling and simple random sampling. The researchers obtained the following number of participants for each treatment using the Slovin's formula. Both the control group and the experimental Group 1 had 24 out of 29 students. The experimental Group 2 had 23 out of 29 students.

\section{Materials}

- Results of the Semi-final examination (Science, Technology, and Society subject)

- Grades on the Midterm examination (Science, Technology, and Society subject)

- Mobile phones 
- Daily Note Sheet

- After-experimen evaluation)

evaluation sheet (for personal

\section{Procedure}

The researchers informed each class about the experiment. It was assumed that the participants were willing to be part of the experiment.

The participants were briefly informed about the methodology and the relevance of the study. However, the real purpose and nature of the study was not disclosed until the experiment was finished to avoid external and internal contaminations of results.

The participants in each section represented each of the different treatments. Section 1201 was the control group wherein basically no treatment was provided, but they were simply asked to take down notes of their study habits. Section 1202 served as the first experimental group wherein the participants were asked to visualize the goal of achieving a grade of 1.00 (98-100) and to evoke the emotion of happiness and pride upon achieving that goal on Science, Technology, and Society (STS) subject for their Semi-final examination. Lastly, Section 1203 stood as the second experimental group wherein the participants were told to visualize the goal of achieving a grade of 1.00 (98-100) and to evoke the emotion of happiness and pride upon achieving that goal as well as the journey or actions toward the goal like studying and reviewing lectures and notes, listening to the professor during classes, taking down notes, actively participating in class discussions, going to the library to study, doing group studies, and turning down friends who invite them to go out.

Each participant was to carry out the instructions for seven consecutive days each morning upon waking up for five minutes. They were reminded by the researchers every day for seven days through personal monitoring and SMS messaging. If they were not able to do so, then they were told to do it before they go to sleep.

The participants took the Semi-final examination on the scheduled day of the exam which was the date indicated in the university calendar.

The researchers took the results of the Semi-final examination as well as the Midterm examination from the Science, Technology, and Society (STS) professor for statistical evaluation.

After the experiment, the participants were debriefed (that is explaining the true nature and purpose of the study).

\section{E. Research Matrix}

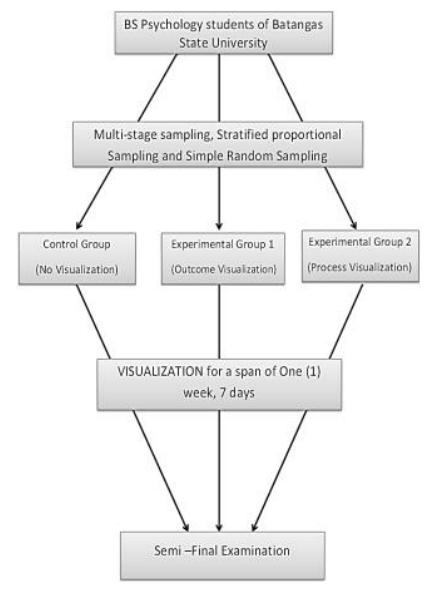

\section{RESULTS}

TABle I: Mean and Standard Deviation of ACAdEMic PeRformance OF PARTICIPANTS IN STS SUBJECT

\begin{tabular}{c|c|c|c|c}
\hline \multirow{2}{*}{ Group } & \multicolumn{2}{|c|}{$\begin{array}{c}\text { Midterm } \\
\text { Mean } \mathrm{s}\end{array}$} & \multicolumn{2}{c}{$\begin{array}{c}\text { Semi-final } \\
\text { Mean }\end{array}$} \\
& 90.13 & 5.83 & 85.83 & 8.93 \\
\hline Control & 88.87 & 6.11 & 90.52 & 7.43 \\
\hline Experimental1 & 86.52 & 8.74 & 88.43 & 10.16 \\
\hline Experimental2 & & & & \\
\hline
\end{tabular}

The mean shows where the data is centered. The table presents the mean scores for the Midterm examination of the control group of 90.13, the experimental Group 1 of 88.87 , and the experimental Group 2 of 86.52 . It can be noted that the control group got the highest mean score. On the other hand, the mean score for the Semi-final examination of the control group was 85.83, the experimental Group 1 was 90.52, and the experimental Group 2 was 88.43.

The standard deviation shows how spread the data is. The table shows that the standard deviation for the Midterm of the control group was 5.83, the experimental Group 1 was 6.11 , and the experimental Group 2 was 8.74 . On the contrary, the standard deviation for the Semi-final of the control group was 8.93, the experimental Group 1 was 7.43 , and the experimental Group 2 was 10.16.

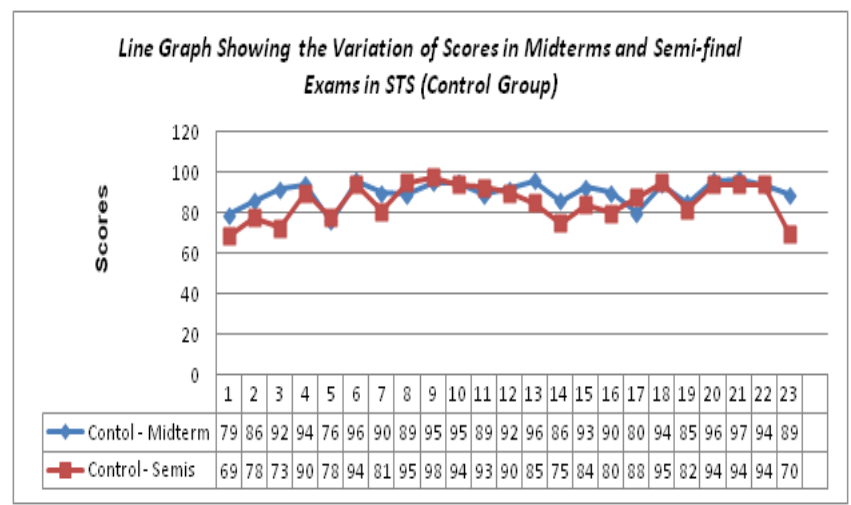

Fig. 1. Distribution of scores of respondents in the Control Group.

It can be noted that the result of the Midterm examination of the control group is higher compared to their Semi-final examination.

Line Graph Showing the Variations of Scores in Midterm and Semi-final Exams in STS (Experiemental Group 1)

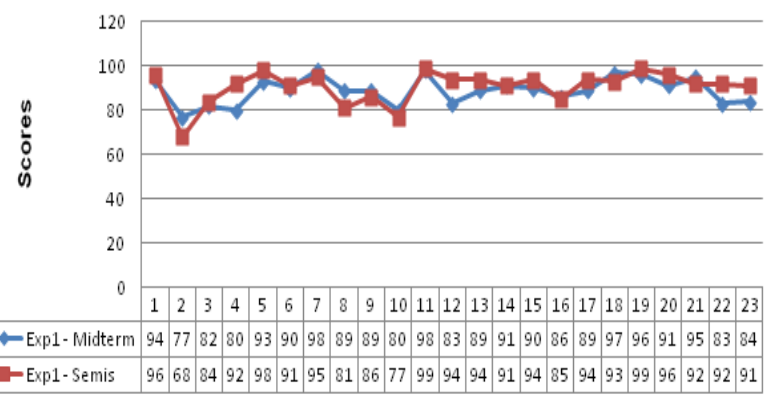

Fig. 2. Distribution of scores of the respondents in the Experimental Group 1

Fig. 2 shows the variation of scores of Midterm and Semi-final of the experimental Group 1. It can be noted that the Semi-final exam improved a little in this treatment. 
Line Graph Showing the Variation of Scores in Midterm and Semi-final Exams in STS (Experimental Group 2)

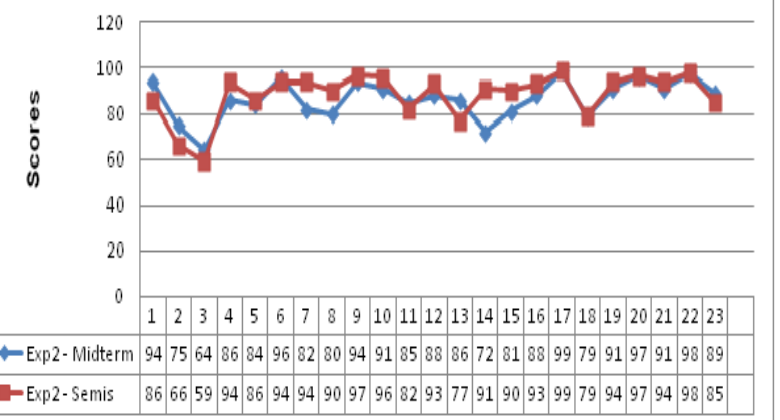

Fig. 3. Distribution of scores of respondents in the Experimental Group 2.

Fig. 3 shows the variation of scores of the Midterm and Semi-final examination of the experimental Group 2 which improved a little as well.

TABLE II: DIFFERENCE ON PARTICIPANTS’ ACADEMIC PERFORMANCE FOR MIDTERM AND SEMI-FINAL EXAMINATION

\begin{tabular}{c|c|c|c|c}
\hline Group & p-values & $\begin{array}{c}\text { Computed } \\
\text { t-values }\end{array}$ & $\begin{array}{c}\text { Decision on } \\
\text { Ho }\end{array}$ & $\begin{array}{c}\text { Verbal } \\
\text { Interpretation }\end{array}$ \\
\hline Control & 0.009 & 2.87 & Reject & Significant \\
\hline Exp 1 & 0.16 & -1.44 & $\begin{array}{c}\text { Failed to } \\
\text { Reject }\end{array}$ & Not Significant \\
\hline Exp 2 & 0.20 & -1.33 & $\begin{array}{c}\text { Failed to } \\
\text { Reject }\end{array}$ & Not Significant \\
\hline
\end{tabular}

Table II shows the representation of scores of respondents in their Midterm and Semi-final examination.

Since the p-value of 0.009 is lower than 0.05 level of significance, the computed t-value of 2.87 is found to be significant. This can also mean that the control group differssignificantly in their academic performance compared to the experimental groups.

Specifically, it can be noted that majority of the participants in the control group shows lower grade results in their Semi-final examination compared to the Midtermexamination. On the other hand, participants in the experimental groups gained higher test results compared to the control group but it is not high enough to be statistically significant.

TABLE III: DIFFERENCE ON THE PERFORMANCE OF PARTICIPANTS IN THEIR SEMI-FINAL EXAMINATION IN STS SUBJECT

\begin{tabular}{c|c|c|c|c}
\hline $\begin{array}{c}\text { Pairwise } \\
\text { comparison }\end{array}$ & p-value & $\begin{array}{c}\text { Computed } \\
\text { t-value }\end{array}$ & $\begin{array}{c}\text { Decision } \\
\text { on Ho }\end{array}$ & $\begin{array}{c}\text { Verbal } \\
\text { Interpretation }\end{array}$ \\
\hline Exp1 vs Exp2 & 0.43 & 0.80 & $\begin{array}{c}\text { Failed to } \\
\text { Reject }\end{array}$ & Not Significant \\
\hline $\begin{array}{c}\text { Control vs } \\
\text { Exp1 }\end{array}$ & 0.059 & -1.938 & $\begin{array}{c}\text { Failed to } \\
\text { Reject }\end{array}$ & Not Significant \\
\hline $\begin{array}{c}\text { Control vs } \\
\text { Exp2 }\end{array}$ & 0.36 & -0.93 & $\begin{array}{c}\text { Failed to } \\
\text { Reject }\end{array}$ & Not Significant \\
\hline
\end{tabular}

Table III shows the pairwise comparison of each treatment conditions. The result shows no significant difference in any of the following conditions being compared.

TABLE IV: COMPARISON OF ACADEMIC PERFORMANCE BETWEEN EXPERIMENTAL GROUP 1 AND EXPERIMENTAL GROUP 2

\begin{tabular}{c|c|c|c}
\hline \multicolumn{2}{c|}{ EXPERIMENTAL GROUP 1 AND EXPERIMENTAL GROUP 2 } & $\begin{array}{c}\text { Asymp. Sig. } \\
\text { (2-sided) }\end{array}$ \\
\hline Pearson Chi-Square & $\begin{array}{c}198.567 \\
\text { a }\end{array}$ & $\begin{array}{c}18 \\
0\end{array}$ & 0.163 \\
\hline Likelihood Ratio & 91.728 & $\begin{array}{c}18 \\
0\end{array}$ & 1.000 \\
\hline $\begin{array}{c}\text { Linear-by-Linear } \\
\text { Association }\end{array}$ & 7.776 & 1 & 0.005 \\
\hline N of Valid Cases & 23 & - & - \\
\hline
\end{tabular}

208 cells $(100.0 \%)$ have expected count less than 5. The minimum expected count is .04 .

Table IV shows the comparison of scores between Experimental Group 1 (Outcome Visualization) and Experimental Group 2 (Process Visualization). The data shows that the results are not significant. Therefore, the two approaches have equal effects on the variable being measured.

\section{DISCUSSION}

The experiment "Effects of Visualization on Academic Performance of College Students" was conducted in order to determine the effects of outcome visualization and process visualization as differentiated by Pham and Taylor (1999) [4], assigned to experimental Group 1 and experimental Group 2, respectively, on the academic performance of Psychology students at Batangas State University. It also determined the more effective method of visualization between the two means.

The study's main goal about visualization was tested and interpreted after experimentation. The study done by Shelley Taylor and Lien Pham of UCLA showed that the process visualization group performed better than the outcome visualization group. There was also a control group, and the results showed that outcome visualization improved two points while process visualization increased by eight points, but Taylor also expressed doubts that the outcome visualization may not lead an individual to achieve one's goal [5].

In the experiment done by the researchers, the two experimental groups represented the outcome visualization and process visualization groups wherein scores were tested and statistically analysed. Results indicated that the two approaches in visualization showed the same effect in improving academic performance. The comparison between two groups showed a p-value of 0.163 which was higher than 0.05 level of significance. The computed value of 198.567 was found to be not significant. This could also mean that the performance of experimental Group 1 exposed to outcome visualization approach does not vary with the performance of experimental Group 2 exposed to process visualization approach.

The experimenters gathered 24 participants for the control group and the experimental Group 1 while experimental Group 2 had 23 participants. One participant for both the control group and the experimental Group 1 was removed 
because the researchers were informed later on that they were not enrolled in Science, Technology, and Society subject (STS).

Various studies were done to determine factors affecting students' academic performance. These factors are "communication, learning facilities, proper guidance, and family stress" [6]. According to Carol Jo Durr, a negative attitude toward a subject or course would demonstrate less effort than on an anticipated class, thus, considering motivation as one factor as well [7]. The best indicator contributing to high student performance is the higher level of socio-economic status according to Farooq, Chauhdhry, Shafiq\&Berhanu [8].English competence and active class participation are the most important factors for a positive effect on students' performance. On the other hand, missing classes frequently and the less number of hours spent studying are most important factors for a negative effect on students' performance according to Harb\& El-Shaarawi [9].

Results showed no significant difference on the effects of outcome visualization and process visualization to the academic performance of psychology students. The researchers believed that willingness to participate in the act of visualization contributed to its effectiveness. According to Walter J. Freeman, an act of perception "is a step in a trajectory by which brains grow, reorganize themselves and reach into their environment to change it to their own advantage" [10]. In general, participants who actively took part and were more focused on visualization got the benefit of closely achieving or achieving the target goal. Participants were asked to describe their experience and comments about the activity which ranged from being enjoyable to being boring, from being willing to simply following when reminded according to their own convenience. Since perception is affected by experience, motives, and emotions, the participants had varying degrees of involvement with regard to visualization [11].

\section{CONCLUSION}

Based on the findings, the researchers came up to the following conclusions:

1) Visualization is statistically insignificant in terms of academic performance.

2) Students who do process and outcome visualization score higher compared to the control group.

3) Based on the findings of the study, the two approaches on visualization, i.e. outcome visualization and process visualization are equally effective in improving academic performance.

Based on the results of the experimental study, the following recommendations can be considered for improvement:

1) Other variables may be studied by future researchers on visualization such as age or age group, gender, length of time, or perception.

2) Visualization should be closely monitored as much as possible and provide a more detailed means of proper visualization to obtain more accurate results.
3) Future researchers may consider using only participants who are willing and will actively participate in visualization or use a within-subject group design to precisely determine whether visualization is an effective means of achieving the goal.

\section{ACKNOWLEDGMENT}

This research would not have been possible without the guidance and help of several individuals who, in one way or another, contributed and extended their valuable support in the preparation and completion of this paper.

First and foremost, the researchers would like to thank the teachers and the faculty of the College of Arts and Sciences specially to Psychology professorswho molded them to become competent students and to the whole BatStateU community. This achievement is for them.

The researchers would also like to recognize their classmates and friends who gave them the everlasting support and confidence that they can finish this research successfully. They have been their aide and inspiration in every step of the way.

The researchers would like to thank theirfamilies who gave them unwinding support and love which is something beyond words to describe. They are forever grateful to them.

E. A. Bulaquiña would like to give a special mention to her son who has been her inspiration for all her most recent accomplishments including this study.

Finally,the authors offer this piece of humble work tothe Almighty God.For answering their prayers and giving them the knowledge to make this an accomplishment, to God be the glory!

\section{REFERENCES}

[1] B. Bobbins. (February 2010). How to really use visualization to achieve your goals-no bs secret stuff here. Don't Step In the Poop: How to Avoid Screwing up Your Life and Your Career. [Online]. Available: http://dontstepinthepoop.com/visualization-for-success-goals

[2] A. Reyes. (April 2012). Does visualization really work? Here's evidence that it does. Expert Enough: Just Enough to be Dangerous. [Online].

Available: http://expertenough.com/1898/visualization-works

[3] A. LeVan. (December 2009). Seeing is believing: the power of visualization. Psychology today. [Online]. Available: http://www.psychologytoday.com/blog/flourish/200912/seeing-is-beli eving-the-power-visualization.

[4] J. Dean. (March 2011). The right kind of visualisation. Psyblog Understand your mind. [Online]. Available: www.spring.org.uk/2011/03/the-right-kind-of-visualisation.php

[5] R. M. King. Thinking without knowledge. King's Psychology Network. [Online]. Available. http://www.psyking.net/id205.htm

[6] I. Mushtaq and S. N. Khan, "Factors affecting students' academic performance," Global Journal of Management and Business Research, vol. 12 , no. 9, pp. 3-4, June 2012

[7] C. J. Durr, "Factors affecting student performance in principles of macroeconomics courses," Issues in Political Economy, vol. 8. pp. 5-7, July 1999.

[8] M. S. Farooq, A. H. Chaudhry, M. Shafiq, and G. Berhanu, "Factors affecting students' quality of academic performance: a case of secondary school level," Journal of Quality and Technology Management, vol. 7, no. 2, pp. 6-11, December 2011.

[9] N. Harb and A. El-Shaarawi (July 2006). Factors affecting students' performance. Munich Personal RePEc Archive. [Online]. 82(5). pp. 8-14. http://mpra.ub.uni-muenchen.de/13621/1/MPRA_paper_13621.pdf

[10] W. J. Freeman. (February 1991). The physiology of perception. Scientific American. [Online]. 264(2). pp. 13. Available: http://sulcus.berkeley.edu/flm/ms/physio.percept.html 
[11] G. Johns and A. M. Saks, Organizational Behaviour Understanding and Managing Life at Work, 6th ed., Pearson Education, 2010, ch. 3.

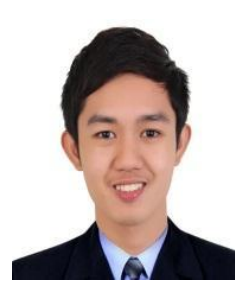

Niño Fredrico L. Narvacan was born on August 31, 1993 in Calaca, Batangas, Philippines. He is currently a fourth year student of Batangas State University taking up Bachelor of Science in Psychology.

Mr. Narvacan was the Financial Manager of the Psychological Organization for the Promotion of Mental Health (POPMH) under the Philippine Mental Health Association (PMHA) Lipa-Batangas Chapter from July 2011 - August 2013. He is also a consistent elected officer of the university - based organization, Psychology Student's Society (PSS) of Batangas State University from 2010 - 2012. His research interest includes environmental psychology, cognitive and biological science and human resource development studies.

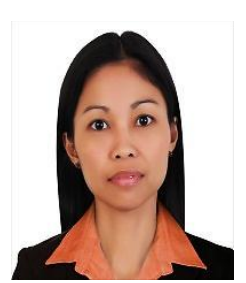

Evangeline Atienza-Bulaquiña is a resident of the Philippines and was born on November 19, 1979 Evangeline is currently a fourth year BS Psychology student at Batangas State University, Batangas City, Philippines. She is also a Registered Chemist in the Philippines with a BS Chemistry degree from the same institution in 2000

She has years of experience working as a Laboratory Analyst in a food manufacturing plant. She also has years of experience as a Medical Transcriptionist in an office-based setting. Currently, she is a full-time Psychology student whose primary interest is career counseling.

Ms.Atienza-Bulaquiña is a member of the Integrated Chemists of the Philippines, Philippine Mental Health Association, and Psychology Students Society.

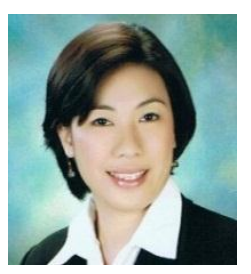

Lucille D. Evangelista was born on July 25, 1977 in Alamada, North Cotabato, Philippines. She received her Bachelor's degree in Clinical Psychology at Polytechnic University of the Philippines (1998), received her Master's degree on Educational Psychology in 2003 with distinction as a Cum Laude at University of Santo Tomas, and finished her Ph. D. in Psychology in 2008 from the same university.

She is currently the assistant director of the Testing and Admission Officeat Batangas State University. She is also a College Professor in the same institution since 1998.

Dr. Evangelista is affiliated with the Psychological Association of the Philippines as an Associate and a member of the following organizations: National Confederation of Public and Private School Educators of the Philippines, MAVEC Specialist Foundation, Philippine Association for Teacher Education, BatStateU Faculty Association, and Teacher's Network. 